\title{
Development of Interactive Learning Multimedia "Mejabando" for Improving Critical and Creative Thinking Skills in Indonesian Language Learning Class V Elementary School
}

\author{
Gebriela Sandang ${ }^{1}$, Wagiran ${ }^{2}$, Lita Latiana ${ }^{3}$ \\ ${ }^{1}$ Master Program, Student of Primary Education, ${ }^{2,3}$ Master Program, of Primary Education \\ Universitas Negeri Semarang, Semarang City, Indonesia. \\ Corresponding Author: Gebriela Sandang
}

DOI: https://doi.org/10.52403/ijrr.20220251

\begin{abstract}
This study aims to produce android-based learning multimedia. The research method used is $R \& D$ research with the ADDIE development model (analysis, design, development, implementation, evaluation). The steps in the research include analyzing, designing, developing, implementing, and evaluating. Data collection techniques in this study include interviews, questionnaires, tests, and documentation. The trial was carried out using the One Group Pretest-Posttest Design. The results of this study are (1) the need for multimedia mejabando learning in the high category (2) the validity of the interactive multimedia mejabando from the material expert got a score of 4.18 in the good category and 4.64 from the material expert in the good category (3) multimedia practicality is in the very practical category with a score of $87 \%$, $88 \%$ and $89 \%$ (4) the effectiveness of interactive multimedia learning mejabando can be seen from the results of the students' pretest and posttest. Critical thinking skills get an N-Gain score of 0.66 in a fairly effective category and $\mathrm{N}$-Gain score for creative thinking skills of 0.57 in a moderately effective category. Based on the results of the research obtained, it can be concluded that the interactive multimedia mejabando learning to improve critical and creative thinking skills in learning Indonesian for fifth-grade elementary school is practical, valid and effective for use in learning.
\end{abstract}

Keywords: Multimedia, critical thinking, creative thinking, Indonesian Language

\section{INTRODUCTION}

The era of the industrial revolution 4.0 requires educational institutions to develop students' hard skills and soft skills such as the ability to think creatively, critically, innovatively, and interpersonally so that they are ready to face challenges in the industrial revolution era. These skills are not innate, but these skills are acquired from experience. Therefore, the task of educators is to organize learning in such a way that all aspects of these 21 st-century skills can be trained (Redhana, 2019). One concrete evidence that the Indonesian government has implemented in facing this era is encouraging all levels of education to take advantage of advances in digital technology that is adapted to the curriculum, preparing human resources in utilizing ICT (Information and Communication Technologists) preparing facilities and infrastructure, as well as developing character values and values. optimize the ability of students (Nazar et al., 2020). Quality education will produce quality human resources, so they can compete in the 21st-century. The Assessment and Teaching of 21st Century Skills (ATC21S) divide 21st-century skills into 4 domains, namely way of thinking, way of working, tools for 
working, and skills for living in the world (Griffin \& Care, 2015). The way of thinking category includes creativity, innovation, and critical thinking. Therefore, education needs to equip students with creative thinking and critical thinking skills. Critical and creative thinking is a central thinking ability. Critical thinking is a valuable skill that can be trained in schools and becomes a learning goal at all levels of disciplines (Thompson, 2011). Creative thinking involves the ability to generate original ideas, to understand new and unexpected relationships (Kargar et al., 2013). Creative thinking ability is a person's ability to create something new, either in the form of an idea or a real work that is relatively different from the existing one (Noviyana, 2017). Critical and creative thinking skills need to be instilled in students from an early age when students are in elementary school. Habituation to think critically and creatively from an early age is very necessary because critical and creative thinking skills can be improved through a habit, this statement is supported by the opinion of Kurniasari \& Setyaningsih, (2020) which states that if the ability to think critically and creatively is not an indicator of success education in elementary schools, this will hurt harm the development of students when they are at a higher level of education. Informal education, schools can improve critical and creative thinking skills by integrating learning materials. One of the lessons that can be used to improve critical and creative thinking skills is Indonesian. Indonesian language learning has many materials that can make students develop critical and creative thinking skills. This is because Indonesian language subjects have a lot of material that allows students to solve problems through various types of texts such as descriptive text, narrative text, biographical text, observational report text, explanatory text, and procedure text. In addition, increasing students' critical and creative thinking skills can be done through the use of learning media (Firdaus et al., 2020).
The results of the study program for international students assessment (PISA) 2018 Indonesia is ranked 74th out of 79 participating countries as measured by the level of intelligence of students, in the fields of science, mathematics, and reading. In addition, in the 2015 global creativity index survey, Indonesia, which was ranked 115th out of 139 countries, is said to be low in creative thinking skills, the contributing factor is the weak thinking skills of students (OECD, 2018). This was also explained by the fifth-grade teacher at SD IT Bina Amal Semarang through interviews, explaining that due to the COVID-19 pandemic which required distance learning, the Indonesian language learning process did not make students develop creative thinking skills and think critically. In addition, teachers have not been able to develop learning media that can improve thinking skills.

Based on the explanation above, information is obtained that in the learning process students can have the opportunity to learn the knowledge gained by using the technology they use to study independently such as using multimedia so the purpose of this research is to produce multimedia in improving creative thinking skills and students' critical thinking, in learning Indonesian in Class V Elementary School.

\section{MATERIALS \& METHODS}

This research was conducted at SD IT Bina Amal Semarang. This study uses the $R \& D$ research method by following the ADDIE development model development syntax (analysis, design, development, implementation, evaluation). The research procedure is explained as follows:

\section{Analysis}

The researcher conducted a needs analysis, identifying the problems (needs) of students concerning the Indonesian language material. The analysis was carried out to obtain information about the competencies needed by students, about how they learn, the knowledge and attitudes of students towards learning Indonesian (Hamzah, 2019). 


\section{Design}

At the design stage, the steps taken are making storyboards and flowcharts, designing devices for multimedia learning, designing learning materials or learning outcomes, and evaluating learning outcomes. Next, the researcher makes a draft of learning multimedia which contains the design of the application media that will be made.

\section{Development}

At the development stage, the researcher realized a multimedia application draft using the required software (Pawana et al., 2014) the researcher used the software construct 2 . The media development product test in this study was carried out in two stages, namely, expert validation and product testing. After the development process is complete, the media will then be validated by the media validator and learning material validator. The media was also tested on a limited basis to a small group of students, to determine the feasibility of the developed media. If in the process of evaluating the test by the validator there are things that must be corrected, then make improvements and modifications to the media so that they are by following per under the recommendations.

\section{Implementation}

After the media is validated and declared feasible, the next step is the application of the media to the selected class. The implementation of learning media is here to direct students to achieve learning competence, improve students' critical and creative thinking skills (Hamzah, 2019). This implementation stage consists of 3 stages, namely individual tests, small group tests, and large group tests. In the implementation of large group trials, a preexperimental one-group (pretest-posttest) design was used.

\section{Evaluation (evaluation/feedback)}

The evaluation stage is the stage to see the success of the system made with the developed learning media, by following per under. That with this learning media, students will improve their critical and creative thinking skills.

In this study, the validity of the data was carried out by using the credibility test (internal validity), namely by triangulating the data. The purpose of triangulation is to increase the theoretical, methodological, and interpretive strength. Triangulation is also defined as the activity of checking data through various sources, techniques, and time. Next is the transferability test (external validity) so that the research report is systematic, detailed, and can be trusted by the readers, the researchers also carry out expert validity on the materials, media, and instruments used in the research. The third is the test of dependability which is also known as reliability. Before the researcher conducts the research, the test that will be used is tested for reliability first. Multimedia development starts from validation by experts. The validators in this study consisted of material experts, media. After being validated by experts and practitioners then revised according to suggestions and input. After that, it was tested. In this study, there are two aspects to be measured, namely the ability to think critically and creatively, to measure these abilities the researcher has provided tests that have been tested for validity, reliability, discriminatory power, level of difficulty, this is in line with the opinion (Mar'ah et al., 2021) before researching the reliability of the measuring instrument, it must be tested first to produce reliable data.

\section{RESULT \& DISCUSSION}

This research was conducted to develop a valid, practical, and effective interactive multimedia mejabando. The process of developing learning media in this study begins with the first stage, namely the design stage with steps (1) Studying the syllabus used in learning Indonesian in class 
5, theme 5, sub-theme 3 (2) identifying the characteristics of students in terms of their learning needs. This step is done by distributing questionnaires to grade 5 students (3) making planning documents about the visualization that will be displayed and materials and other things needed in making the product, and (4) determining and collecting visualization sources, including animation. and videos. The second stage of the development procedure carried out is the design stage with steps (1) preparing all the materials that will be used in making interactive multimedia and (2) designing learning media to be developed which begins with making flowcharts and storyboards.

The process of developing the multimedia mejabando begins after all materials and supporting materials such as videos, texts, animation, and audio concepts are declared ready to be poured into the form of the initial product. The programs used in the process of making this product are constructed 2, adobe photoshop CS3 for processing images, kinemaster for making learning videos. The process of making the program can run smoothly, quickly, and more organized because it is based on flowcharts and storyboards that have been prepared and the readiness of materials that have been prepared according to user characteristics. After the product is finished, the product is then tested by material and media experts. The process of making the program ends by reviewing the resulting product by trying to run the program. If no more errors are found, then the product is ready for testing. Product testing is carried out in stages, namely validity, practicality, and effectiveness tests. The final result of the initial product is packaged in the form of an application and if it has passed the next test stage the application is published to the Google Play Store.

\section{Test the Validity of the interactive Multimedia mejabando}

Product validation tests are carried out in 3 stages, namely alpha test, beta test, and product validation (summative evaluation). Alpha test is a validation carried out by learning material experts and learning media experts. The beta test was conducted to know the practicality of interactive learning multimedia by students and practitioners. Respondents in the beta test are students of class VI. Product validation (summative evaluation) was carried out to know the quality of the product developed from the multimedia functionalization itself and the student's critical and creative thinking skills after using the interactive multimedia table that was developed. The material in the developed multimedia was validated by 1 material expert, namely Dr. Panca Dewi Purwati M.Pd. Meanwhile, the media expert was validated by Dr. Sigit Saptono M.Pd. The results of the material expert validation were obtained by giving the product in the form of a hard file to make it easier to revise the material and the language used accompanied by a validation sheet in the form of a questionnaire sheet with a linkert scale reference. The material expert questionnaire is described in 22 indicators with details of the content aspects of 12 indicators and learning aspects of 10 indicators. Briefly, the results of the expert validation of the material and interactive multimedia media developed by the mejabando are presented in the table below:

Table 1. Recap of the average score obtained from the validation of material experts

\begin{tabular}{|l|l|l|}
\hline Aspect & Score & Criteria \\
\hline Material/content & 4,16 & Good \\
\hline Learning & 4,20 & Good \\
\hline Average & 4,18 & Good \\
\hline
\end{tabular}

Based on the table above, it can be seen that the recap of the average score of the validation results by material experts scores 4.18 and is in a good category. The comments and suggestions from material experts are as follows: (1) the rules of writing words in Indonesian are good and correct and are guided by EBI (2) indicators are added and adjusted to the objectives of learning and evaluation Media validation in this study was carried out by Dr. Sigit Saptono M.Pd. Validation is carried out by referring to the validation sheet provided. 
The questionnaire for media experts consists of 2 aspects, namely the display and programming aspects. These two aspects are described in 24 indicators with details of 14 indicators of display aspects and 10 indicators of programming aspects. In more detail, the results of the validation by media experts will be presented in the table below:

Table 2. Recap of the average score of the material expert validation results

\begin{tabular}{|l|l|l|}
\hline Aspect & Score & Criteria \\
\hline Appearance & 4,78 & Very good \\
\hline Programming & 4,50 & Very good \\
\hline Average & 4,64 & Very good \\
\hline
\end{tabular}

The results of the validation by media experts obtained an average score of 4.64 with very good criteria. In addition to obtaining quantitative data, it is also in the form of suggestions and comments as follows: (1) references taken from the internet, should be given a source (2) the application is less flexible because students have to install it first. The results of the media and material expert validation were then analyzed as input and suggestions for the first revision.

\section{Reliability}

Questions to measure critical and creative thinking skills were tested on students at SD Bina Amal Semarang with a total of 14 students. The validity and reliability test of this item was conducted to determine the level of validity of the measuring instrument to be used. Question validation was processed with the help of SPSS version 26 and Excel. The following are the results of the validation of critical and creative thinking skills:

Table . 4 results of the validity test of critical thinking skills

\begin{tabular}{|l|l|l|l|}
\hline Number & r count & r table & Description \\
\hline 1 & 0,767 & 0,5324 & Valid \\
\hline 2 & 0,904 & 0,5324 & Valid \\
\hline 3 & 0,611 & 0,5324 & Valid \\
\hline 4 & 0,350 & 0,5324 & Invalid \\
\hline 5 & 0,817 & 0,5324 & Valid \\
\hline 6 & 0,689 & 0,5324 & Valid \\
\hline 7 & 0,277 & 0,5324 & Invalid \\
\hline 8 & 0,843 & 0,5324 & Valid \\
\hline
\end{tabular}

After testing the validity for critical thinking questions, 6 valid questions and 2 invalid questions were then tested for reliability. The reliability test using Cronbach's Alpha correlation was processed using the help of SPSS Version 26 software. The results of the item reliability test showed the reliability of $0.805>0.600$ because the value because the Alpha value was $>0.600$ so that the items could be said to be reliable.

Table .5 results of the validity test of creative thinking skills

\begin{tabular}{|l|l|l|l|}
\hline Number & r count & r table & Description \\
\hline 1 & 0,661 & 0,5324 & Valid \\
\hline 2 & 0,580 & 0,5324 & Valid \\
\hline 3 & 0,655 & 0,5324 & Valid \\
\hline 4 & 0,625 & 0,5324 & Valid \\
\hline 5 & 0,514 & 0,5324 & Invalid \\
\hline 6 & 0,266 & 0,5324 & Invalid \\
\hline
\end{tabular}

The results of the validity calculation for creative thinking questions are 4 valid questions and two invalid questions. After knowing the valid questions, then the reliability test using Cronbach's Alpha correlation is processed using the help of SPSS Version 26 software. The results of the reliability test items on the ability to think creatively show the reliability of $0.620>0.600$, because the value for Alpha value $>0.600$ so that the items can be said to be reliable.

\section{The Practicality of mejabando Interactive Multimedia}

The next process is testing the practicality of multimedia. Data were obtained through student and practitioner responses to the developed multimedia. This testing process was carried out at SD IT Bina Amal Semarang with a total of 10 students and 2 practitioners. The steps taken in this small-scale trial process were that students (1) were given directions regarding the objectives and procedures for the exam before students used the multimedia tabletop learning. (2) students are asked to give value to the multimedia that has been used by filling out the questionnaire that has been given. The following are guidelines for assessing the practicality of multimedia:

Table Category percentage practicality of multimedia

\begin{tabular}{|l|l|}
\hline interval & Description \\
\hline $86 \%-100 \%$ & Very practical \\
\hline $71 \%-85 \%$ & Practical \\
\hline $56 \%-70 \%$ & Practical enough \\
\hline $41 \%-5 \%$ & Less practical \\
\hline
\end{tabular}




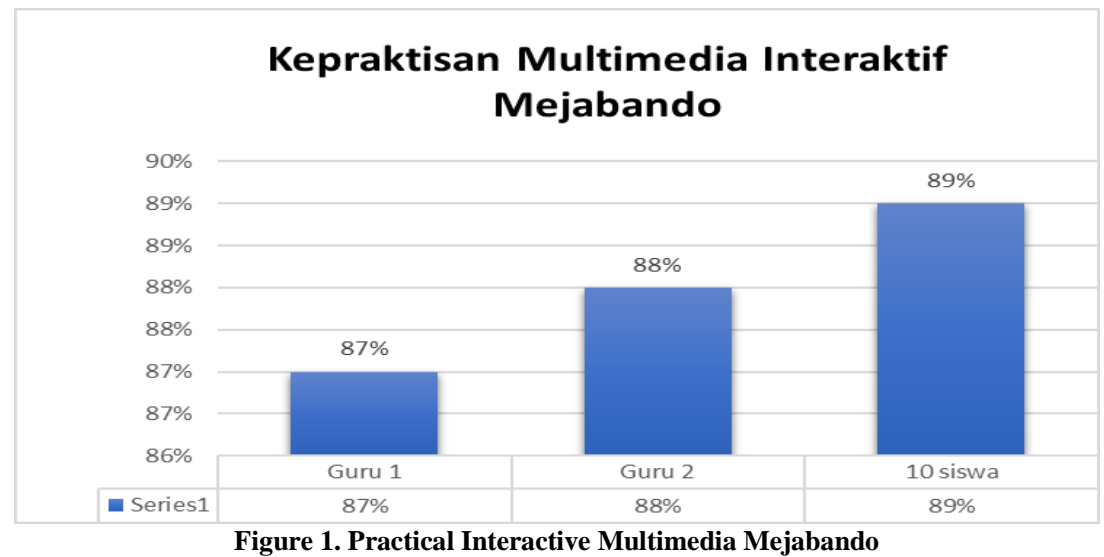

The results of the overall calculation of the responses of students and teachers obtained a score with a very practical. Based on the table above, it can be concluded that the percentage of practicality based on the assessment of 2 teachers and 10 students is $87 \%, 88 \%$, and $89 \%$. Comments were also given by students about the mejabando multimedia. In general, students revealed that the multimedia display was very interesting because it resembled a form of a game, the evaluation in multimedia can make students improve their ability to analyze multimedia, the learning process for Indonesian language material also becomes more interesting, very helpful students to carry out the learning process independently. After the multimedia was valid and practical, a large-scale trial was carried out with as many as 20 students as respondents to determine students' critical and creative thinking skills. The trial was carried out in 5th grade at SD IT Bina Amal Semarang.

3. The Effectiveness of mejabando's Interactive Multimedia Normality test a Normality test is used to test whether the data is normally distributed or not. The normality test of critical thinking ability test data using the one-sample KolmogorovSmirnov technique at a significance level of 0.05 in the SPSS 26 program.

Table 5 the results of the normality test of the critical thinking ability test class

\begin{tabular}{|l|l|l|}
\hline class & Kolmogorov-Smirnov & Shapiro-wilk \\
\hline & Sig. & Sig. \\
\hline Pretest & 0,200 & 0,665 \\
\hline postest & 0,200 & 0,511 \\
\hline
\end{tabular}

Table 6 normality test results for creative thinking ability test class

\begin{tabular}{|l|l|l|}
\hline class & Kolmogorov-Smirnov & Shapiro-wilk \\
\hline & Sig. & Sig. \\
\hline Pretest & 0,182 & 0,340 \\
\hline postest & 0,166 & 0,240 \\
\hline
\end{tabular}

Table 5 shows the results of the normality test of critical thinking skills in the pretest and posttest classes using the Kolmogorov-Smirnov and Shapiro-wilk tests. The data is declared normally distributed if the significance value obtained is more than 0.05. Based on the table shows a significance value of more than 0.05 . So, the tested data can be continued with the final stage of data analysis.

\section{Evaluation Results of Critical and Creative Thinking Ability Test}

Critical thinking indicators that the research uses in this study are interpreting, analyzing, concluding, evaluating, explaining, self-regulating. conclude. While the creative thinking indicator consists of 4 indicators including fluency, flexibility, novelty, elaboration. Assessment of critical and creative thinking skills is carried out before learning (pretest) and after learning (posttest). Giving the pretest aims to determine the initial ability of students while the posttest is given to determine the ability of students after participating in the learning process using the interactive multimedia mejabando. Analysis of critical and creative thinking test results is calculated using $\mathrm{N}$-gain. $\mathrm{N}$-Gain is used to determine the improvement of students' critical thinking skills before and after using 
the interactive multimedia mejabando. Values are obtained from student learning outcomes at the time of pretest and posttest. The following is the categorization of the $\mathrm{N}$ gain value: Table 6 Categories of Nomalized gain.

Table 6 Categories of Nomalized gain

\begin{tabular}{|l|l|}
\hline Interval & Criteria \\
\hline$(<\mathrm{g}>) \geq 0,7$ & High \\
\hline $0,7>(<\mathrm{g}>)>0,3$ & Middle \\
\hline$(<\mathrm{g}>) \leq 0,3$ & Low \\
\hline
\end{tabular}

The results of the students' critical thinking ability test scores are as follows:

Table 6 Scores of N-Gain Results of Students' Critical and Creative Thinking Test

\begin{tabular}{|l|l|l|l|l|}
\hline Data & Pretest & Posttest & $\begin{array}{l}\text { N- } \\
\text { Gain }\end{array}$ & Interpretation \\
\hline $\begin{array}{l}\text { Critical } \\
\text { thinking skills }\end{array}$ & 54,04 & 84,01 & 0,66 & Middle \\
\hline $\begin{array}{l}\text { Creative } \\
\text { thinking skills }\end{array}$ & 57,75 & 81,5 & 0,57 & Middle \\
\hline
\end{tabular}

Table 6 shows the results of the calculation of the $\mathrm{N}$-Gain value. The $\mathrm{N}$-gain value data for critical thinking skills with an $\mathrm{N}$-Gain score of 0.66 is in the medium category, while the $\mathrm{N}$-Gain score for creative thinking skills with a score of 0.57 is in the medium category. This shows that the use of interactive multimedia tables is effective for improving critical and creative thinking skills. This is in accordance with the results of Wiyono's research in (Agustina et al., 2019) that learning using interactive multimedia can make it easier to learn concepts that are abstract and can adapt styles. different learning. The data also proves that students' critical and creative thinking skills have increased. This proves that learning using multimedia combined with learning models in the 2013 curriculum will foster students' critical and creative thinking skills because the learning process using this media begins with reading text and analyzing the images or facts presented. In addition, the difference in student learning outcomes during pretest and posttest is very significant, this is in accordance with the research of Indrawan et al., (2013) with the use of interactive multimedia, the average student learning outcomes will differ significantly before and after using interactive multimedia. On the other hand, The results of this study are in line with the behaviouristic learning theory proposed by Thorndike that the learning process is a mechanistic process between stimulus and response, so it can be concluded that interactive multimedia can produce stimulus and get responses from students so that information processing will be realized. In addition, the learning theory that supports the results in this study is Piaget's cognitive learning theory Piaget, the impact in the use of multimedia in learning can direct students' attention, be able to present material in an interesting form, for example in the form of images and animations, and display various animations that will be able to understand. students related to the concept being studied in more depth (Damayanti, 2013).

\section{CONCLUSION}

Mejabando learning multimedia is multimedia developed to improve students' critical and creative thinking skills. This multimedia was developed based on the needs of students. Mejabando learning multimedia was developed through several stages of testing, namely validity, practicality, and effectiveness. The results of the multimedia validation analysis for material experts are described in 22 indicators with details of the content aspects of 12 indicators and learning aspects of 10 indicators. The score of the validation results by material experts is 4.18 in the good category with details of the material aspects with a score of 4.16 and the learning aspect of 4.20 in the good category. As for media experts, the questionnaire used is described in 24 indicators with details of 14 indicators of display aspects and 10 indicators of programming aspects. The media expert's validation score is 4.64 with the details of the display aspect 4.78 and the programming aspect 4.50 . The practicality of multimedia is obtained from the results of 
the assessment of 2 practitioners and 10 students. The practicality of multimedia can be seen from the percentage level obtained. The results of the analysis of the practicality of multimedia are $91 \%, 92 \%$, and $91 \%$ of the percentage, it can be concluded that the multimedia mejabando is very practical based on practicality criteria. After the multimedia is valid and practical, it is then tested on a large scale to determine the effectiveness of the interactive multimedia mejabando in improving critical and creative thinking skills. The results of the analysis show that the average $\mathrm{N}$-gain value for critical thinking skills is 0.66 and is in the moderate or quite effective category, while the $\mathrm{N}$-gain value for creative thinking skills is 0.57 with a moderate or quite effective category. Based on these results, it can be concluded that the interactive multimedia mejabando is quite effective in improving students' critical and creative thinking skills in learning Indonesian in 5thgrade elementary school. So it can be concluded that the overall interactive multimedia mejabando is valid and practical to use and is quite effective in improving students' critical and creative thinking skills.

\section{Acknowledgement: None}

\section{Conflict of Interest: None}

\section{Source of Funding: None}

\section{REFERENCES}

1. Agustina, I., Astuti, D., Sumarni, R. A., \& Bhakti, Y. B. (2019). Pengembangan Multimedia Interaktif Berbasis. Abdimas Dewantara, 2(2), 107-114.

2. Damayanti, F. (2013). Pembelajaran Berbantuan Multimedia Berdasarkan Teori Beban Kognitif untuk Meningkatkan Kemampuan Menyelesaikan Masalah Program Linear Siswa X TKR 1 SMKN 1 Doko. Jurnal Pendidikan Sains, 1(2), 133140.

3. Firdaus, F. Z., Suryanti, S., \& Azizah, U. (2020). Pengembangan Multimedia Interaktif Berbasis Pendekatan SETS Untuk Meningkatkan Kemampuan Berpikir Kritis
Siswa Sekolah Dasar. Jurnal Basicedu, 4(3), 681-689.

https://doi.org/10.31004/basicedu.v4i3.417

4. Indrawan, I. M., Suharsono, N., \& Tegeh, I. M. (2013). Untuk Pembelajaran Komputer Grafis Bagi Siswa Desain Komunikasi Visual DI SMK e-Journal Program Pascasarjana Universitas Pendidikan Ganesha. 3.

5. Kargar, F. R., Ajilchi, B., Goreyshi, M. K., \& Noohi, S. (2013). Effect of Creative and Critical Thinking Skills Teaching on Identity Styles and General Health in Adolescents. Procedia - Social and Behavioral Sciences, 84(2003), 464-469. https://doi.org/10.1016/j.sbspro.2013.06.585

6. Kurniasari, Y. R., \& Setyaningsih, Y. (2020). Measuring Student's Critical Thinking Ability by Adapting California Critical Thinking Skills Test to Primary School Students. Lingua Didaktia, 14(2), 144-160.

https://doi.org/10.24036/ld.v14i2.109126xx $\mathrm{xx}$

7. Mar'ah, N. khairiyatul, Rusilowati, A., \& Purwanti, E. (2021). Development of Science Literature Instruments Contained Ethnoscience in Science Subject for Class IV Elementary School Students. International Journal of Research and Review, 8(9), 423-435. https://doi.org/10.52403/ijrr.20210954

8. Nazar, M., Oktarina, A., \& Puspita, K. (2020). Pengembangan Aplikasi Pembelajaran Interaktif Berbasis Android Untuk Membantu Mahasiswa Dalam Mempelajari Materi Larutan Elektrolit Dan Nonelektrolit. Jurnal Pendidikan Sains Indonesia (Indonesian Journal of Science Education), 8(1), 39-54. https://doi.org/10.24815/jpsi.v8i1.16047

9. Noviyana, H. (2017). Pengaruh Model Project Based Learning Terhadap. Jurnal Edumath, 3(2), 110-117.

10. OECD. (2019). Programme for international student assessment (PISA) results from PISA 2018. Oecd, 1-10. https://www.oecdilibrary.org/education/pisa-2018-results-

volume-iii_bd69f805-

en\%0Ahttps://www.oecd-

ilibrary.org//sites/bd69f805-

en/index.html?itemId=/content/component/b d69f805-en\#fig86

11. Pawana, M. G., Suharsono, N., \& Kirna, I. M. (2014). Pengembangan Multimedia 
Gebriela Sandang et.al. Development of interactive learning multimedia "Mejabando" for improving critical and creative thinking skills in Indonesian language learning class V elementary school.

Interaktif Berbasis Proyek Dengan Model ADDIE Pada Materi Pemrograman Web Siswa Kelas X Semester Genap Di SMK Negeri 3 Singaraja. E-Journal Program Pascasarjana Universitas Pendidikan Ganesha, 4, 1-10.

12. Redhana, I. W. (2019). Mengembangkan Keterampilan Abad Ke-21 Dalam Pembelajaran Kimia. Jurnal Inovasi Pendidikan Kimia, 13(1).
How to cite this article: Gebriela Sandang, Wagiran, Lita Latiana. Development of interactive learning multimedia "Mejabando" for improving critical and creative thinking skills in Indonesian language learning class $\mathrm{V}$ elementary school. International Journal of Research and Review. 2022; 9(2): 402-410. DOI: https://doi.org/10.52403/ijrr.20220251 